
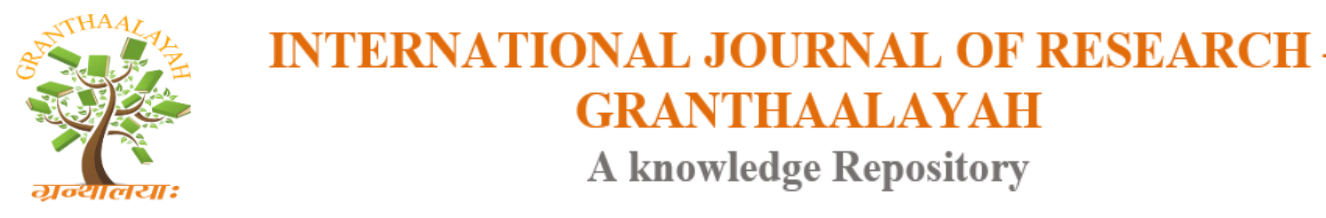

Social

\title{
A STUDY ON "THE EFFECTS PROJECT BASED LEARNING STRATEGY ON ACADEMIC ACHIEVEMENT AMONG HIGH SCHOOL STUDENT"
}

\author{
G. Sudha Elizabath ${ }^{1}$, Dr. T. Sangeetha ${ }^{2}$ \\ ${ }^{1}$ M.Ed. Student, R.V.S. College of Education, India \\ ${ }^{2}$ Assistant Professor in Commerce Education, R.V.S. College of Education, Coimbatore, India
}

\begin{abstract}
In India most of the classrooms are still teacher centered, where the students have to sit and listening to the teachers lecture. In emerging 21 st century the student's needs to develop skills like reasoning, problem-solving, creative, collaboration, critical thinking, communication etc., the study aimed to examine the Project Based Learning method in teaching high school students. The investigator adopted experimental method to study the PBL method in teaching high school students. For the study sample of 60 IX std students from schools situated in Coimbatore district in Tamil Nadu was selected. The finding reveals that is inferred that there is a difference between PBL method of teaching and conventional teaching among High school's students.
\end{abstract}

Keywords: Project-Based Learning; Conventional Teaching; Academic Achievement and Teaching and Learning.

Cite This Article: G. Sudha Elizabath, and Dr. T. Sangeetha. (2018). "A STUDY ON "THE EFFECTS PROJECT BASED LEARNING STRATEGY ON ACADEMIC ACHIEVEMENT AMONG HIGH SCHOOL STUDENT"." International Journal of Research - Granthaalayah, 6(6), 503-517. https://doi.org/10.29121/granthaalayah.v6.i6.2018.1396.

\section{Introduction}

The aim of education in ancient India was to solve the problem of death by achieving knowledge of the whole truth of which life and death are arts and phases. The aim was not simply abstract and theoretical. There were practical and solid aims too. The first was the acquisition of knowledge. This was evident in the Vedic period. Inculcation of social and civic duties in the minds of the students was also regarded as an important aim of education in those days. Education for occupation was another important aim. Character training and moral education was regarded as very important aim of ancient Indian education.

Now, Indian education system basically promotes rat race among our children. Our children are unable to do critical analysis of anything, for example our history, culture and religion. They take the line of establishment or the views of predominant majority. They are simply not able to look 
things from their own perspective. If you want a society should become a lot better than we must develop a culture of looking at things critically.

The children of today are gearing up to become adult citizens of tomorrow. The growth is parallel to the future of our country, reflected through quality of the present education system. A school must stimulate curiosity in the young, impressionable minds and equip them with tools to be better human beings.

It widely accepted that the learning process is instrumental in shaping one's personality and the way he/she deals with situations of life. The shift of thoughts from bookish knowledge to knowledge of life, in schools, has brought forth a sea of change. People have warmed up to the idea of education being the key to a well-rounded development instead of just a mean to acquire degrees and monetary success in life. Education must facilitate the cultivation of a healthy thought process and groom our cognitive abilities. In the present competitive world, education is a basic necessity for human beings after food, clothes and shelter.

In the educational field, a teacher has an important role in the society and he builds up a strong, durable and ideal society. According to Dr. Radhakrishnan," Teacher's place in the society is of vital importance. He acts as the point of transmission of intellectual traditions and technical skill from generation to generation and helps to keep them the lamps of civilization burning". Hence teacher is considered as the real architect of the nation.

The National Policy on Education (1986) has rightly stated, "No people can rise above the level of its teachers". So, for the development of our country, it is very important to have a good teacher. Since it is the noblest profession, teacher should have proper training before entering, into teaching. During training period, it is a chance for every trainee to develop all his qualities.

Project-based learning (PBL) is a student-cantered pedagogy that involves a dynamic classroom approach in which it is believed that students acquire a deeper knowledge through active exploration of real-world challenges and problems. It is a style of active learning and inquiry-based learning.

Project-based learning naturally lends itself to differentiated instruction. By design, it is studentcantered, student-driven, and gives space for teachers to meet the needs of students in a variety of ways. PBL can allow for effective differentiation in assessment as well as daily management and instruction. We all need to try out specific ideas and strategies to get our brains working in a different context. Here are some specific differentiation strategies to use during a PBL project. Students learn to work in a community, thereby taking on social responsibilities. The most significant contributions of PBL have been in schools languishing in poverty stricken areas; when students take responsibility, or ownership, for their learning, their self-esteem soars. It also helps to create better work habits and attitudes toward learning. Although students do work in groups, they also become more independent because they are receiving little instruction from the teacher. PBL strategy is more effective than conventional method on achievement of school students. This method not only paved the way for attainment of instructional objectives, but also cater to the overall development of the personality. 
Students are becoming more creative, work efficient and smart after the introduction of ProjectBased Learning. PBL is an effective classroom activity that shifts boring, one way interactive and teacher centered environment to interdisciplinary and student-centered activity (Santhosh Bhaskar 2013).

There are many studies and literature showing that students learn better when they are physically engaged in the learning process. Research shows that there is a direct relationship between the number of senses engaged in learning and the amount and quality of retention achieved over time (Stice 1987).

The concept of project-based learning is powerful: actively working through a project allows students to show creativity and adaptability that may be lacking in students who are exposed only to a traditional classroom setting. In India, project-based learning places students' focus on solving issues of personal interest and mitigates the high pressure of traditional education (Nathaniel Siegel 2016).

Project-based learning is not without its challenges. It's demanding of students -- and of teachers. Especially for teachers who have never experienced PBL before, projects require planning and management skills that may be unfamiliar. What's more, PBL puts teachers in the role of facilitator rather than classroom expert. Teachers may benefit from professional development to help them expand their classroom "tool kit" of teaching strategies. Just as it's essential that students buy in to PBL, teachers also need to feel empowered. Support from administrators, parents, and other community members can help teachers and students to overcome challenges and make the most of PBL opportunities.

As PBL gains advocates and gathers momentum, the education community will continue to exchange ideas and collaborate on projects, making this powerful method of preparing students for the future even better.

Project-Based Learning strategy is more effective than conventional activity-oriented method on achievement of school students. This method not only paved the way for attainment of instructional objectives, but also cater to the overall development of the personality. There are many studies and literature showing that students learn better when they are physically engaged in the learning process. Research shows that there is a direct relationship between the number of senses engaged in learning and the amount and quality of retention achieved over time (Stice 1987).

Effectiveness in the teaching and learning of in schools has remained a focal point of research efforts for many years. There has been a gradual paradigm shift in education from transmission of information to the processes by which knowledge is acquired. Emphasis in education, therefore, is now on students' involvement in their own learning through active participation in the learning process. This study investigates the effects of Project-Based Learning strategy on achievement among High School Students. 


\section{Hypothesis of the Study}

1) There is no significant mean score difference between the pre-test and post-test scores of the control group of high school students, exposed to teaching using conventional teaching and the pretest and post test scores of the experimental group of high school student exposed to teaching using PBL.

2) There is no significant mean score difference between the pre-test and post-test scores of the control group of high school students, exposed to teaching using conventional teaching and the pretest and post test scores of the experimental group of high school student exposed to teaching using PBL.

\section{Materials and Methods}

The methodology consists of procedures and techniques for conducting the study. The problem selected for the present study is concerned with experimental type. Experimental method is a scientific method. It is oriented to the future in the sense that the researcher is seeking to evaluate something new. The purpose of experimentation is to verified functional relationship among phenomena under controlled conditions.

\section{Pre-Test Post-Test Control Group}

The design is also called as 'Randomized Control-group Pre-test Post-test design'. Here the investigator has undertaken a study with the objective of comparing the Concept Mapping method with the traditional method for teaching science at IX standard level. Two equated groups are formed by randomly assigning subjects to the groups. Both the groups are administered a similar achievement test pre-test. The treatments are randomly assigned to the groups. The duration of the treatment had been similar. At the end of the treatment, both the groups are administered the same achievement test. The scores on these tests are termed as post-test scores. In this design the development variable (achievement test) has been measured before (pre-test) and after (post-test) the treatment (Project Based Learning Strategy) in the randomized equivalent groups. The difference between means pre-test and post-test is found in order to ascertain whether the experimental treatment produced a significant effect.

\section{Design of the Study}

An experimental design is to the researcher what a blueprint to an architect. Selection of a particular design is based on the purpose of the experiment, the type of the variables to be manipulated, and the conditions or limiting factors under which it is conducted. Experimental design can be classified as pre-experimental, Quasi-experimental, True experimental and Statistical. Here the investigator has adapted the True experimental design which includes pre-test, post-test, control group design. In the present study the investigator will adapt parallel group experimental design. In true experimental designs, researchers can randomly assign test units and treatment to an Experimental group. Here, the researcher is able to eliminate the effect of extraneous variables from both the Experimental and Control group. The study uses the experimental method for Project Based Learning. 


\section{Parallel groups design}

We first consider the parallel design in which two randomized experiments are conducted in parallel. Specifically, we randomly split the sample into two experiments. In the causal inference literature, Pearl (2001), implicitly considered an identification strategy under such a design called parallel group design. Our identification analysis differ from Pearl's in that he considered identification under a sequential ignored assumption that was similar. We also derive the sharp bounds on the average indirect effects in the absence of any assumption that is not justified by the design itself. The Rubin Causal Model provides a common way to describes a randomized experiment. Rubin Causal Model provides a framework for defining the casual parameters (i.e., the effects of a randomized treatment on an outcome), the analysis of experiments can take a number of forms. Most commonly, randomized experiments are analyzed using ANOVA, Student's t-test, Regression analysis, or a similar statistical test. In this study the investigator has $t$ test to analyze the result.

In investigator administered pre-test for both control and experimental group students. Experimental group was given treatment and the control group was not given any treatment, after that, the post-test was conducted both control and experimental groups. Finally, the gain score was calculated to subtract pre-test achievement marks from post achievement marks.

\section{Population and Area of the Study}

Population for the present study includes IX standard students in Coimbatore District, Tamil Nadu, India. The sample of 60 students was taken for the study from Global Pathways Matriculation School in Coimbatore District of IX standard was selected for the final study. The students were divided into two equivalent groups such as Control and Experimental group based on school, which will be flexible to conduct the study.

\section{Tool for the Final Study}

In this present study the Project based Learning Model Relevant Learning for 21st Century by Pacific Education Institute was modified to fulfil this study needs and adapted. The framework of this model gives and eagle eye view on student's activity and teacher activity. The layout of the student's worksheets will give the students an overview of their activity. The tool for this study consisted of two parts. The first part consisted of personal data sheet and the second part consisted of 44 multiple choice questions made by Sangeetha 2015.

\section{Personal Data Sheet}

Personal data sheet consists to collect the primary information about the sample. It consists of collecting information like name, class, school, gender, age, nature of the family, parent's educational qualification and parent's occupation.

\section{Multiple Choice Questions}

The tool consists of 44 multiple choice questions from standard IX science chapter Pollution and Ozone Depletion. In this study, the following research tools were used by the investigator. The research tools were,

- Project based teaching model of science for IX std students.

- Criterion Referenced Test (CRT) was constructed and validated for pre-test and post-test of the students by the investigator. 


\section{Data Collection}

Data collection is the process of gathering and measuring information on targeted variables in an established systematic fashion, which then enables one to answer relevant questions and evaluate outcomes. Data collection will comprise responses in interviews, observation and document study. Document analysis is something that will happen concurrently with interviews as they will provide the basis for refining interview questions.

For this study, the investigator got the permission from the Headmaster of the high school managements and also class teachers and science teachers for conducting the experiment. The topic is Pollution and Ozone Depletion. The investigator gave dates for conducting the pre-test, teaching the topic and post-test. The investigator followed the norms and schedules given by the schools and collected the data.

\section{Pre-Test}

The investigator before conducting the test had good relationship with the students to ensure their co-operations for the study. The investigator will told the students about the purpose o the study and instructed about the pre-test questionnaire. The questionnaire with 44 questions and 44 marks had been used for pre-test. The time allotted for this is 45 minutes. The pre-test will be add to both the Control group and Experimental group. The answer scripts were corrected. It helped the investigator to find out the achievement of the students before the treatment and to know whether the two groups are similar.

\section{Treatment}

The topics were randomly selected from the science book of class IX. Accordingly, chapter eight deals with Pollution and Ozone Depletion will be chosen. Under this chapter, different kind of pollution, global warming, ozone depletion, greenhouse effect, acid rain will be thoroughly presented according to the time table. The Experimental group exposed to the Project based learning method and the control group by Traditional teaching methods of usual talk and chalk method. Both the groups were taught for two weeks of class from 18.01.2018 to 1.02.2018.

\section{Post-Test}

After the teaching was completed through respective methods, the post-test was conducted to the Experimental and Control groups. The same questions which were used for the pre-test was used for the post-test to know the knowledge acquisition regarding the topic had developed. The question paper consisted of 44 questions for 44 marks. The time allotment was 45 minutes. The answer scripts were scored to find the difference between groups after teaching through Project Based learning strategy.

\section{Statistical Techniques}

After the collection of pertinent data through the appropriate tools and techniques, the next step in the process is to organize and interpret it through various statistical techniques. In the present study the investigator will be using two types of statistical analysis such as descriptive and inferential analysis. Descriptive analysis refers to transformation of raw data into a form that will facilitate easy understanding and interpretation. The common ways of summarizing data are by calculating average, range, standard deviation, frequency and percentage of distribution. Under inferential analysis, inferences are drawn on population parameters based on sample results. 


\section{Results and Discussions}

After collecting the data, the researcher has to accomplish the task of analysing and interpreting the data. Interpretation means an adequate exposition of the true meaning of the material presented in terms of the purpose of the study reported and of the chapter and selection of topic involved. In the present study the researcher collected data from 60 students. In the present study the researcher statistically analysed the data using mean score difference, slandered deviation, T-test and ANOVA tests. The researcher used the SPSS software to statistically analyse the collected data.

\section{Analysis and Interpretation of the Data}

\section{Hypotheses: 1}

There is no significant mean score difference between the pre-test and post-test scores of the control group of high school students, exposed to teaching using conventional teaching and the pre test and post test scores of the experimental group of high school student exposed to teaching using PBL.

Table 4.1: Pre test and Post test Mean scores of the control and experimental groups

\begin{tabular}{|l|l|l|l|l|l|l|l|}
\hline Method of instruction & \multicolumn{3}{|l|}{ Pre-test } & \multicolumn{2}{l|}{ Post test } & 't' value \\
\hline & $\mathbf{N}$ & Mean & $\begin{array}{l}\text { Std. } \\
\text { Deviation }\end{array}$ & N & Mean & $\begin{array}{l}\text { Std. } \\
\text { Deviation }\end{array}$ & \\
\hline $\begin{array}{l}\text { Conventional } \\
\text { teaching }\end{array}$ & 30 & 24.57 & 5.72 & 30 & 33.37 & 5.34 & $22.86^{* *}$ \\
\hline PBL Method & 30 & 19.57 & 6.4 & 30 & 35.97 & 4.77 & $12.37^{* *}$ \\
\hline Total & 60 & \multicolumn{7}{|l|l|}{} \\
\hline
\end{tabular}

** Significant at 0.002 level

The above table shows that the calculated ' $t$ ' value for the pre-test and post test scores for the experimental group was 12.37 and for the control group, it was 26.86 respectively. The calculated ' $t$ ' values were greater than the table value of 2.5758 at 0.002 and 0.05 level of significance respectively. Then ' $p$ ' value was found to be $\leq 0.0001$. This shows that the difference in pre-test and post test mean scores is statistically significant. The mean scores for the group instructed through PBL method was 19.57 which had increased to 35.97 in the post test and for the group exposed to Conventional teaching, it was 24.57, which had increased to 33.37 respectively. The increase in the post test mean scores was the highest for the groups instructed through PBL method. The higher post test mean score may be due to the technique used in PBL method of teaching which helped the students in retention.

Hence, the hypothesis stated as: "There is no significant mean score difference between the pretest and post-test scores of the control group of high school students, exposed to teaching using conventional teaching and the pre test and post test scores of the experimental group of high school student exposed to teaching using PBL" was rejected. 


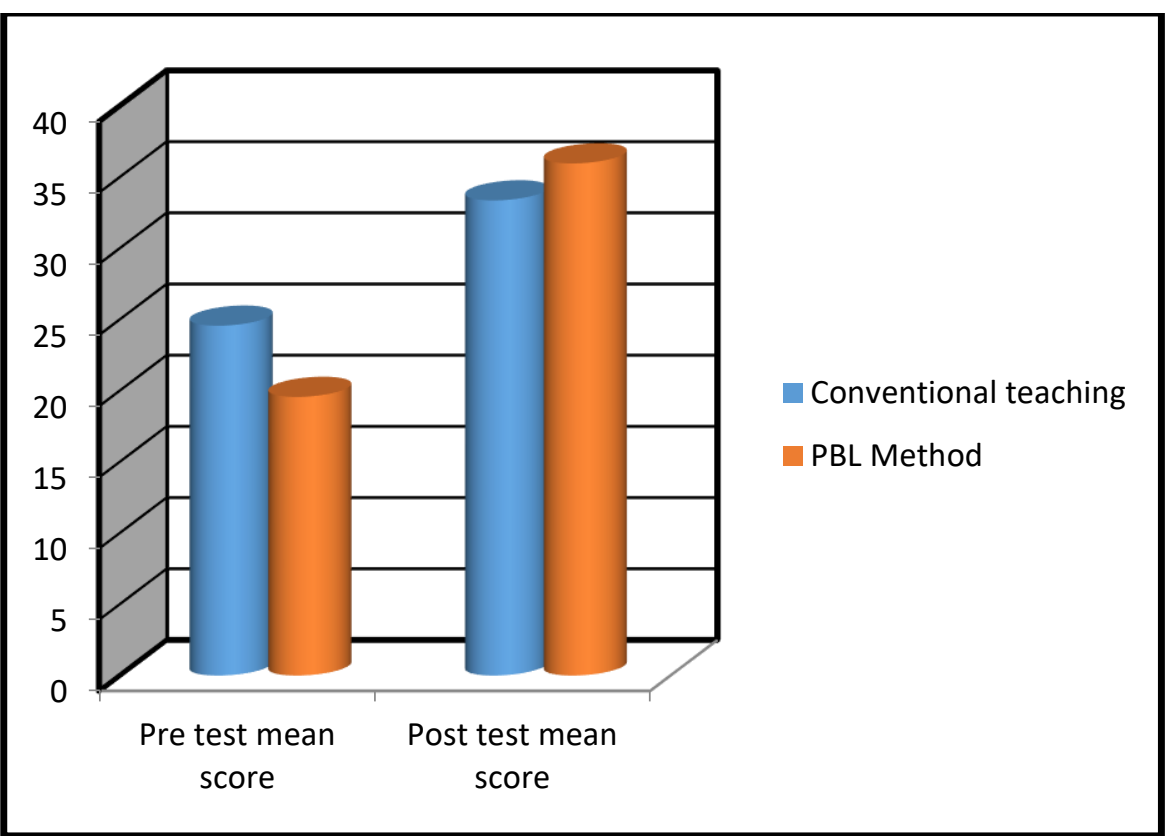

Figure 4.1: Pre test and Post test Mean scores of the control and experimental groups

\begin{tabular}{|l|l|l|l|}
\hline \multicolumn{2}{|l|}{} & \multicolumn{2}{|l|}{ PRETESTPOST TEST } \\
\hline \multirow{4}{*}{ PRETEST } & Pearson Correlation & 1 & $.617^{* *}$ \\
\cline { 2 - 4 } & Sig. (2-tailed) & & .000 \\
\cline { 2 - 4 } & $\mathbf{N}$ & 60 & 60 \\
\hline \multirow{3}{*}{ POST TEST } & Pearson Correlation & $617^{* *}$ & 1 \\
\cline { 2 - 4 } & Sig. (2-tailed) & .000 & \\
\cline { 2 - 4 } & $\mathbf{N}$ & 60 & 60 \\
\hline
\end{tabular}

Figure 4.1: Correlations between the control and experimental groups

The above table shows that the calculated correlation between the conventional teaching method and PBL method is .617 and significance at the 0.01 level. The correlation may be due to the technique used in PBL method of teaching which helped the students in retention.

Hence, the hypothesis stated as: "There is no significant mean score difference between the pretest and post-test scores of the control group of high school students, exposed to teaching using conventional teaching and the pre test and post test scores of the experimental group of high school student exposed to teaching using PBL" was rejected.

\section{Hypotheses: 2}

There is no significant mean score difference between the pre-test of the control groups of IX standard, exposed to teaching of science using conventional teaching and the pre-test of the experimental groups of IX standard, exposed to teaching of science using Project based Learning method. 
Table 4.2: Mean score difference between the pre-test of the control groups and experimental groups

\begin{tabular}{|l|l|l|l|l|}
\hline Grouping & Mean & Std. Deviation & 't' test \\
\hline Pre Test & Conventional teaching 30 & 19.575 .72 & 3.07 \\
\hline & PBL method & 30 & 24.406 .4 & \\
\hline
\end{tabular}

**Significant at 0.01 level

The above table shows that the calculated ' $t$ ' value for the pre-test scores for the experimental and control group was 3.07. The calculated ' $t$ ' value was greater than the table value of 2.5758 at 0.01 level of significance. The ' $p$ ' value was found to be $\leq 0.0001$. This shows that the different in pretest mean score is statistically significant.

Hence, the hypothesis stated as: "There is no significant mean score difference between the pretest of the control groups and experimental groups of high school students using PBL" was rejected.

\section{Conclusions and Recommendations}

The study clearly reveals that there is a significant impact of instruction through Project Based Learning method among high school students.

\section{Education Implication}

The findings of this study outlined that the use of Project Based Learning strategy among high school students is significant. This study contributes to the students learning and achievement. The benefits to the teacher includes increased experience and skill in planning and teaching a Project Based approach and deeper understanding of pedagogical and content knowledge. Over time students benefited by engaging in content-rich, motivating experiences that will optimize their learning and increase their overall interest and performances. The benefits to the administrators include increase understanding and awareness of Project Based Learning approach to teaching and learning a more competent and knowledgeable teacher and increased students performance.

\section{Limitations of the Study}

The limitations of the study are as follows:

- The study is conducted only in schools in the Coimbatore District.

- The study will be administered only to High School students.

- The study will be administrated only to Matriculation school.

- A sample of 60 students will be taken for the study.

- The study is done by using a tool adapted from.

\section{Acknowledgements}

I thank Almighty God for shower me with knowledge and strength to complete my project successfully. I thank my husband, father daughter and friends for their moral support and encouragement throughout these days. 
I wholeheartedly thank my Guide Dr. Sangeetha M.com., M.Phil(com)., M.Ed., Ph.D. Assistant professor in Pedagogy of Commerce, RVS College of Education, Coimbatore for sharing her knowledge and guide me in a right way.

I am eternally grateful to Mrs. Theresa Mersky for her financial support for my study.

I also thankful to Mr. Jim Brickell Principal, Global Pathways School, Coimbatore for granting permission to undertake the research work in school.

\title{
5. Appendices
}

\author{
Appendix - A \\ Personal Data \\ Name of the Student \\ Class and Section \\ Gender \\ Name of the School \\ Nature of the School \\ Age \\ Type of the School \\ Locality of the School \\ Medium of Instruction \\ Area of Resident \\ Nature of the family \\ Father's Qualification \\ Mother's Qualification \\ Father's Occupation \\ Mother's Occupation \\ Male/Female \\ Girls/Boys/Co-Education \\ : Government/Private/Aided \\ : Rural/Urban \\ : Tamil/English \\ : Rural/Urban \\ : Nuclear/Joint \\ : Uneducated/School Education/Graduate \\ : Uneducated/School Education/Graduate \\ : Government/Private \\ : Government/Private
}

\section{Appendix - B}

Experimental Study

Pollution and Ozone depletion

CLASS : IX STD

SUBJECT : SCIENCE

MARKS: 44

TIME : 40 minutes

Answer all the questions and mark the correct answer in the respective options.

\section{Multiple Choice Questions}

1. Mercury is hazardous chemicals. The item that contains mercury is
a) Computer disks
b) Thermometer
c) Glass
d) Wooden blocks

2. Animal drug is a waste.
a) Bio-degradable
b) Non-biodegradable
c) Hazardous
d) Toxic

3. is a non-biodegradable waste which may pollute the earth to dangerous levels.

a) DDT

b) CFC

c) Radioactive substances

d) PAN 
4. The only gas that can absorb the sun's dangerous ultraviolet radiation is
a) Carbon dioxide
b) Ozone c) Nitrous gas
d) Nitrogen

5. The amount of Nitrogen present in the atmosphere is
a) $20.9 \%$
b) $1 \%$
c) $30 \%$
d) $78 \%$

6. Particulate means
a) Soot, dust and pesticides b) Fossil fuels c) Gases

d) Solids

7. Incomplete burning of petrol of diesel in vehicles creates poisonous.

a) Carbon dioxide b) Carbon monoxide c) Methane d) Ozone

8. Excessive quantities of carbon dioxide, water vapour, methane and nitrous oxide in the atmosphere, which reflect heat back on to the earth's atmosphere is called the
a) Greenhouse effect
b) Solar radiation
c) Acid rain
d) Reflection
9. Stagnation of water causes pollution.
a) Water
b) Soil c) Air
d) Radioactive

10. The pollutant responsible for ozone holes is
a) Plastic
b) Paper
c) Metals
d) Chlorofluorocarbon
11. Due to water pollution organisms are mainly affected.
a) Land
b) Aquatic
c) Atmospheric
c) Wild

12. The two components that acid rain contain that are most damaging to the environment are
a) Carbon dioxide \& water
b) Carbon dioxide \& sulphur dioxide
c) Nitrogen \& water
d) Sulphuric acid \& nitric acid

13. The process of waste water treatment is known as
a) Swedge
b) Oil
c) Hard
d) Soft gas which is very

14. Taj Mahal is said to be suffering from
a) Acid rain which corrodes marble
b) Fungus
c) Yellowing of the marble
d) Smoke

15. As per world Worle Fund of Nature, the river endangered rivers in the world.
a) Ganga
b) Yamuna
c) Brahmaputra
d) Krishna

16. India celebrates Van Mahotsav every year in the month of in which lakhs of trees are planted across the country.
a) June
b) August
c) July
d) November

17. Loss of chlorophyll in plants is called
a) Pyrolysis
b) Catalysis
c) Meiosis
d) Chlorosis treatment.

18. PAN is called as

a) Peroxyacetyl nitrate b) Isopropyl c) Peroxide aceto nitrogen d) pyro acetyl nitrate

19. The gas which leaked due to Bhopal Gas Tragedy is
a) Isocyanate
b) Isopropyl
c) Methyl isocyanate
d) Methyl cyanide

20. To save our earth from pollution we have to
a) Plant more trees
b) Use more vehicles
c) Clear forests d) Build industries

21. BOD is which leads to death of aquatic organisms.
a) Biological Ozone Demand
b) Biological Oxygen Demand
c) Biological Oil Demand
d) Biological Demand

22. DDT is used as a/an
a) Insecticide
b) Pesticide
c) Fungicide
d) Weedicide 
23. Conservation means
a) To destroy
b) To keep safe
c) To use more
d) To change

24. Pyrolysis is

a) Burning without oxygen b) Roasting c) Burning with oxygen d) Melting 25. causes bone cancer.
a) Strontium-90
b) Cobalt-30
c) Uranium-80
d) Radium-50

26. Leukaemia is a type
a) Bone
b) Blood
c) Brain
d) Lung

27. The unit of sound level is measured in

a) Amperes b) Volts c) Decibels d) joules

28. The Forest Act was formed in the year
a) 1980
b) 1990
c) 1970
d) 1950

29. The average increase in the temperature of the atmosphere is called as
a) Ozone depletion
b) Global Warming
c) Greenhouse effect
d) Acid rain 30 . used as coolant in refrigerators.
a) Chlorofluorocarbons
b) Carbon monoxide
c) Carbon dioxide
d) Methane

31. Global warming can also be reduced by using bulbs.
a) Sodium b) Mercury c) Filament
d) Compact Fluorescent Light (CFL)

32. The ozone layer is present in
a) Stratosphere
b) Troposphere c) mesosphere
d) Ionosphere

33. The formation of ozone hole causes
a) Fever
b) Skin Cancer
c) Breathing problem
d) Malaria

34. Afforestation means
a) Planting trees
b) Cutting down trees
c) Soil erosion
d) Destruction of forest

35. We celebrate water day on
a) June 6
b) March 22 c) May 2
d) July 10

36. is the purest form of water.

a) Tap water b) Well water c) Sea water d) Rain water

37. Decreases in body temperature is called as
a) Hypothermia
b) feaver
c) Hydrothermia
d) Phobia

38. The process of cleaning oil spills by using bacteria is known as
a) Bio unification
b) Bio remediation c) Bio recycling
d) Bio soluble

39. M.S. Swaminathan Research Foundation was established in the year
a) 1998
b) 1978
c) 1975
d) 1988

40. Due to Global warming, the sea level
a) Decreases
b) Drain
c) Increases
d) No change

41. By planting more trees, we get pure
a) Oxygen
b) Nitrogen
c) Hydrogen
d) Helium

42. Industries should be located

a) Near b) Away from

c) In the

d) Anywhere residential areas.

43. Carcinogenic means
a) Poisonous
b) Medicine
c) Cancer causing agent
d) Antibiotics

44. Due to oil spill in the sea and oceans are very much affected.
a) Water birds
b) Plant
c) Human beings
d) Wild animals 


\section{Key for the Pilot Study}

1. b) Thermometer

2. a) Bio-degradable

3. c) Radioactive substances

4. b) Ozone

5. d) $78 \%$

6. a) Soot, dust and pesticides

7. b) Carbon Monoxide

8. a) Greenhouse Effect

9. a) Water

10. a) Chlorofluorocarbon

11. b) Aquatic

12. d) Sulphuric acid

13. a) Swage

14. a) Acid rain which corrodes marble

15. a) Ganga

16. c) July

17. d) Chlorosis

18. a) Peroxyacetyl nitrate

19. c) Methyl isocyanate

20. a) Plant more trees

21. b) Biological Oxygen Demand

22. a) Insecticide

23. b) To keep safe

24. Burning without oxygen

25. a) Strontium -90

26. b) Blood

27. c) Decibels

28. a) 1980

29. b) Global Warming

30. a) Chlorofluorocarbon

31. d) Compact Fluorescent Light

32. a) Stratosphere

33. b) Skin Cancer

34. a) Planting trees

35. b) March 22

36. d) Rain water

37. a) Hypothermia

38. b) Bio-remediation

39. b) 1978

40. c) Increases

41. d) Photosynthesis

42. a) Away from

43. c) Cancer causing agent

44. a) Water birds 


\section{References}

[1] Brigid J.S. Barron. Doing with understanding Lessons From Research on Problem-and ProjectBased Learning. The journal of the Learning Science 1998. 7(3\&4): 271-311.

[2] C. Blumenfeld, Elliot Soloway, Ronald W. marx, Joseph S. Krajcik, Mark Cizdziel and Annemarie Palincsar. Motivating Project-Based Learning: Sustaining the Doing, Supporting the Learning. Educational Psychologist 1991. 26(3\&4): 369-98.

[3] Dr. Abha Bhagat. Inquiry-based learning Assessing students' science skills. Teacher (2017). 11(4): 34-7.

[4] Dr. Pramila Kudva. Changing the learning landscape: Teacher 2017; 11(3): 14-7. Hye-Jung and Cheolil Lim. Peer Evaluation in Blended Team Project-Based Learning: What Do Students Find Important?. Educational Technology \& Society 2012.15(4): 214-24.

[5] Jitendra R. Patel, Dharmik S. Patel, Jasmin Parmar, Ravi Thaker and Rajesh Desai. Original Article Approach of medical students towards project based learning. Indian Journal of Basic and Applied Medical Research 2014; 4(1): 499-502.

[6] Khunyakari, R., Mehrotra, S., Chunawala, S., \& Natarajan, C. Design and technology productions among middle school students: an Indian experience. International Journal of Technology and Design Education 2007; 17(1):5-22.

[7] Markham T. Project Based Learning. Teacher Librarian 2011. 39(2): 38-42.

[8] Rajesh Kannan. R, Shashank Mahajan and R. Rajkumar. An Approach on Effective \& Efficient Project-Based Learning (PBL) School Of Computer Science \& Eng. International Journal of Applied Engineering Research 2016; 11(8): 5920-6.

[9] Tali Tal, Joseph S., Krajic, Phyllis C. and Blumenfield. Urban Schools Teachers Enacting ProjectBased Science. Journal of Research in Science Teaching 2006. 43(7): 722-45.

[10] Stephain Bell. Project-Based Learning 21st Century: Skill for the future. The cleaning house 2010. 83: 39-43.

[11] Y. Yamin, A. Permanasari, S. Redjeki and W. Sopandi. Application of Model Project Based Learning on Integrated Science in Water Pollution. Journal of Physics 2017. 895: 1-8.

[12] http://teachersofindia.org/en/article/project-based-learning

[13] https://nwcommons.nwciowa.edu/cgi/viewcontent.cgi?referer=https://www.google.co.in/\&httpsre $\operatorname{dir}=1 \&$ article $=1007 \&$ context=education_masters

[14] http://www.bie.org/images/uploads/general/21c5f7ef7e7ee3b98172602b29d8cb6a.pdf http://www.huso.buu.ac.th/file/2559/ActiveLearning/Document/11.Design\%20Effective\%20Proj. pdf

[15] http://digitalcommons.unl.edu/cgi/viewcontent.cgi?article=1041\&context=cehsgpirw

[16] http://www.bie.org/images/uploads/general/9d06758fd346969cb63653d00dca55c0.pdf http://www.thehindu.com/features/education/college-and-university/projectbased-learning-anessential-bridge/article6069991.ece

[17] http://edtechreview.in/news/436-best-tools-for-project-based-learning

[18] https://www.google.co.in/url?sa=t\&rct=j\&q=\&esrc=s\&source=web\&cd=10\&cad=rja\&uact=8\&v ed=0ahUKEwi8qOiau6LXAhXDQo8KHV3_Bx4QFghTMAk\&url=http\%3A\%2F\%2Fwww.k12. wa.us\%2FEnvironmentSustainability\%2Fpubdocs\%2FSDPManual2010.doc\&usg=AOvVaw3lvv AoLCDffDE9fzlN8n7D

[19] https://www.google.co.in/url?sa=t\&rct=j\&q=\&esrc=s\&source=web\&cd=1\&cad=rja\&uact=8\&ve $\mathrm{d}=0$ ahUKEwiIwoPCuJ3XAhWJv48KHVZ9BcUQFgglMAA\&url=http\%3A\%2F\%2Fepisteme.hb cse.tifr.res.in\%2Findex.php\%2Fepisteme5\%2F5\%2Fpaper\%2Fdownload\%2F156\%2F29\&usg=A OvVaw2QpCZtogwN-BHoinK1Z2wi

[20] https://www.researchgate.net/publication/226236983_What_do_students_learn_from_designing and_making_a_playground_model

[21] http://navimumbaisciencefoundation.org/common/SUtsav_TC_Proc_2013.pdf

[22] http://citeseerx.ist.psu.edu/viewdoc/download?doi=10.1.1.470.2497\&rep=rep1\&type=pdf 
[23] https://www.edutopia.org/new-skills-new-century

[24] https://www.farmingdale.edu/facultyresources/pdf/practice.pdf

[25] http://journals.sagepub.com/doi/abs/10.2190/LRXX-9AE5-F0YA-E92G

[26] https://link.springer.com/chapter/10.1007/978-81-322-1931-6_76

[27] https://www.nmu.edu/education/sites/DrupalEducation/files/UserFiles/Fox_Tim_MP.pdf

[28] http://hkier.fed.cuhk.edu.hk/journal/wp-content/uploads/2010/06/erj_v21n2_217-234.pdf

[29] http://internal.clarkson.edu/highschool/k12/pdf/project-based.pdf

[30] http://www.kevindsmith.org/uploads/1/1/2/4/11249861/project-based-learning-kevin-smith.pdf

[31] https://www.sciencedirect.com/science/article/pii/S074301670600012X

[32] https://projectbasedlearningrepository.wikispaces.com/file/view/69978994.pdf

[33] http://www.innovationunit.org/wp-content/uploads/2017/04/Work-That-Matters-Teachers-Guideto-Project-based-Learning.pdf

[34] https://borgenproject.org/project-based-learning-india/

[35] http://www.edutopia.org/blog/projects-partnerships-pbl-suzie-boss

[36] http://unesdoc.unesco.org/images/0024/002431/243126e.pdf

[37] http://unesdoc.unesco.org/images/0021/002168/216873e.pdf

[38] http://www.fishwildlife.org/files/ConEd-Project-based-Learning_-Model.pdf

[39] https://pacificeducationinstitute.org/wp-content/uploads/2017/03/Project-based-LearningModel_Guide_FINAL.pdf

[40] http://newlearningonline.com/new-learning/chapter-6/bransford-brown-and-cocking-on-how-thebrain-learns

[41] https://www.colorado.edu/MCDB/LearningBiology/readings/How-people-learn.pdf

[42] https://www.cambridge.org/core/books/cambridge-handbook-of-the-learningsciences/projectbased-learning/355AA45D92D7FCD5D312FD1C343FDBB2

[43] http://daleydoseoflearning.weebly.com/uploads/1/8/7/7/18774020/chapter_19_pbl_kraichik.pdf

[44] http://www.hbcse.tifr.res.in/data/pdf/saurav/title-page

[45] https://www.ncbi.nlm.nih.gov/pmc/articles/PMC4082522/

[46] https://scholarspace.manoa.hawaii.edu/bitstream/10125/100534/1/Chin_William_r.pdf

[47] http://www.ascd.org/publications/books/106031/chapters/The_Nine_Steps_of_ProjectBased_Learning.aspx

[48] http://citl.illinois.edu/citl-101/teaching-learning/resources/teaching-strategies/problem-basedlearning-(pbl)

[49] https://www.prodigygame.com/blog/advantages-disadvantages-problem-based-learning/

*Corresponding author.

E-mail address: sudhaelizabath@ gmail.com 